\title{
Amotosalen Hydrochloride
}

National Cancer Institute

\section{Source}

National Cancer Institute. Amotosalen Hydrochloride. NCI Thesaurus. Code C72699.

The hydrochloride salt form of amotosalen, a synthetic psoralen and light-activated DNA, RNA crosslinking agent, with protective activity ag ainst pathogens such as bacteria, viruses, protozoa, and leukocytes. Prior to administration amotosalen is added to plasma and platelets, then in vivo the agent penetrates pathogens and targets DNA and RNA. Upon activation by ultraviolet $\mathrm{A}$ light, this agent is able to form interstrand DNA and RNA crosslinks and prevents replication. Inactivation of leukocytes can prevent graft versus host disease upon transfusion. 